\title{
HUBUNGAN PH SALIVA DENGAN DMF-T PADA MAHASISWA TINGKAT I PROGRAM DIII KEPERAWATAN GIGI POLTEKKES KEMENKES TASIKMALAYA
}

\author{
Tita Kartika Dewi ${ }^{1}$, Emma Kamelia ${ }^{2}$ \\ ${ }^{1,2}$ Dosen Jurusan Keperawatan Gigi Poltekkes Kemenkes Tasikmalaya
}

\begin{abstract}
ABSTRAK
Proses terjadinya karies gigi dipengaruhi oleh berbagai faktor, diantaranya adalah adanya saliva. Saliva mempunyai derajat keasaman atau Power of Hydrogen $(\mathrm{pH})$. $\mathrm{pH}$ saliva terbagi menjadi 2 kategori yaitu saliva asam dan saliva basa. Saliva yang berperan dalam proses karies gigi adalah saliva yang termasuk kategori asam. Metode penelitian yang digunakan dalam penelitian ini adalah kuantitatif cross sectional. Tujuan penelitian ini adalah untuk mengetahui hubungan $\mathrm{pH}$ saliva dengan DMF-T pada mahasiswa tingkat I Program DIII Keperawatan Gigi Poltekkes Kemenkes Tasikmalaya Tahun 2014. Sampel penelitian berjumlah 36 orang. Hasil penelitian menunjukan bahwa $\mathrm{pH}$ saliva tidak berhubungan dengan DMF-T pada mahasiswa tingkat I Program D III Keperawatan Gigi Jurusan Keperawatan Gigi Poltekkes Kemenkes Tasikmalaya.
\end{abstract}

Kata kunci : DMF-T, pH saliva, Mahasiswa.

\section{ABSTRAC}

Dental Caries incident influenced by many factors, one of them is Saliva. Saliva has the Power of Hydrogen ( $\mathrm{pH}$ ). The $\mathrm{pH}$ of saliva consist of 2 categories there are acid saliva and alkali saliva. The saliva which take a part on dental caries incident is acid saliva. The research method that used is the kuantitatif of cross sectional.. The aim of this research is to know the correlation between Saliva pH with the DMF-T of Tasikmalaya Health polytehnic Dental Nursing first grade student on 2014. The sample of this research are 36 respondent. The result of this research is show that saliva $\mathrm{pH}$ have no correlation to the DMF-T of the student.

Keyword : DMF-T, Saliva $p H$, Student.

\section{PENDAHULUAN}

Saliva adalah cairan kental yang diproduksi oleh kelenjar ludah. Saliva disekresikan oleh 3 pasang kelenjar saliva besar yaitu glandula parotidea, glandula submandibularis, glandula sublingualis, dan beberapa kelenjar saliva kecil seperti glandula sublingualis minor, glandula sublingualis, glandula bukalis, glandula glossopalatina, glandula palatina, glandula molaris dan glandula lingualis. Kelenjarkelenjar tersebut terletak dibawah lidah, daerah otot pipi dan di daerah dekat langitlangit (Ircham, dkk., 1993, Cit. Hanizar, 2005). Saliva sebagian besar dihasilkan pada saat makan, sebagai rangsangan atau reaksi yang berupa pengecapan dan pengunyahan makanan (Kidd, dkk., 1992)

Menurut Kidd, dkk (1992), kecepatan sekresi stimulasi saliva normal pada orang dewasa 1-2 $\mathrm{ml}$ tiap menit, sedangkan menurut Konig \& Hoogendoorn (1982), orang dewasa sehat produksi salivanya 1-1,5 It per hari. Pada individu yang sehat, gigi geligi secara terus menerus terendam dalam air ludah sebanyak $0,5 \mathrm{ml}$ yang akan membantu melindungi gigi, lidah, membran mukosa mulut dan orofaring. Pengeluaran saliva akan berhenti pada saat tidur, sebab pada manusia 
kelenjar liur tidak berproduksi jika tidak dirangsang (Konig \& Hoogendoorn, 1982).

Produksi saliva setiap orang berbeda sehingga didapatkan variasi yang relatif luas dalam volume normal dari produksi saliva setiap harinya. Istilah xerostomia digunakan untuk menggambarkan keadaan seseorang yang menderita gangguan fungsi kelenjar saliva berat, kecepatan sekresi ini bisa turun sampai kurang dari $0,1 \mathrm{ml}$ per menit (Kidd, dkk.,1992). Hypersalivasi untuk menggambarkan keadaan sekresi saliva yang berada di bawah kontrol, dimana keadaan ini sekresi saliva meningkat yang disebabkan oleh produksi berlebih atau jalannya saliva yang tidak lancar (Kusmarjadi, 2010)

Power of Hydrogen $(\mathrm{pH})$ adalah suatu ukuran yang menguraikan derajat tingkat kadar keasaman atau alkali dari suatu larutan. Unit $p H$ diukur pada skala 0 sampai 14, dan dibentuk dari informasi kuantitatif yang dinyatakan oleh tingkat derajat keasaman atau basa yang berkaitan dengan aktivitas ion hydrogen $\left(H^{+}\right)$dengan konsentrasi ion hidroksil $(\mathrm{OH})$, jika konsentrasi $H^{+}$lebih besar dari $\mathrm{OH}$, material disebut asam yaitu apabila nilai $\mathrm{pH}$ adalah kurang dari 7, jika konsentrasi $\mathrm{OH}$ lebih besar dari $H^{+}$, material disebut basa dengan nilai $p H$ lebih besar dari 7 , jika konsentrasi $H^{+}$ sama dengan $\mathrm{OH}$, maka material disebut sebagai material netral. Asam dan basa mempunyai ion hydrogen bebas dan ion alkali bebas. Besarnya konsentrasi ion $\mathrm{H}^{+}$dalam larutan disebut derajat keasaman, untuk menyatakan derajat keasaman suatu larutan dipakai pengertian $\mathrm{pH}$ (Miratania, 2010).

\section{METODE PENELITIAN}

Penelitian ini merupakan penelitian kuantitatif dengan desain cross sectional pada mahasiswa tingkat I Program Studi DIII Keperawatan Gigi Jurusan Keperawatan Gigi Poltekkes Kemenkes Tasikmalaya yang berjumlah 36 responden. Ukuran sample pada penelitian ini dengan total sampling. Data dikumpulkan dengan cara melakukan tes pengukuran $\mathrm{pH}$ saliva dan pemeriksaan
Saliva berperan penting dalam menjaga keseimbangan keadaan pada gigi dan rongga mulut yang dipengaruhi oleh $\mathrm{pH}$ saliva, penurunan $\mathrm{pH}$ yang berulang-ulang akan mengakibatkan keadaan rongga mulut menjadi buruk, hal ini disebabkan karena kadar asam atau basa yang berlebihan, sehingga $\mathrm{pH}$ dalam mulut menjadi tidak stabil, dengan mengkonsumsi makanan yang mengandung kalsium dan fosfor ini akan membantu mengurangi proses kelarutan email (remineralisasi). Makanan yang mengandung kalsium dan fosfor yaitu contohnya: susu, ikan, kacang-kacangan dan yogurt (Masayu, 2008. Cit, Agisty, 2010).

Menurut Soebroto (2009), faktor utama yang menyebabkan karies gigi adalah 1) gigi dan air ludah, bentuk gigi yang tidak beraturan dan air ludah yang banyak dan kental, mempermudah terjadinya karies 2) adanya bakteri penyebab karies, bakteri penyebab karies adalah dari jenis bakteri streptococcus dan lactobacillus 3) makanan yang dikonsumsi, makanan yang mudah lengket dan menempel pada gigi seperti permen dan coklat, memudahkan terjadinya karies.

$D M F-T$ merupakan index karies gigi untuk gigi dewasa, yang menggambarkan keadaan gigi geligi seseorang yang pernah mengalami kerusakan, hilang, perbaikan yang disebabkan penyakit karies gigi. DMF-T merupakan alat ukur untuk karies gigi dewasa yang menggambarkan total life time caries experince (Depkes, R.I., 1995). DMF-T adalah rata-rata elemen karies yang hilang dan yang ditumpat setiap individu (Houwink, dkk., 1993).

kasus DMF-T. Penelitian ini dilakukan dengan dua kali pemeriksaan, yaitu dengan cara mengambil saliva yang ditampung ke dalam cawan plastik sebanyak $3 \mathrm{cc}$ yang telah disediakan dan mengukurnya dengan $\mathrm{pH}$ meter kemudian responden diinstruksikan untuk diperiksa DMF-T. analisa data dengan chi-square. 
Tita K.D, Emma K.' Poltekkes Kemenkes Tasikmalaya; DMF-T, pH saliva, Mahasiswa.

\section{HASIL PENELITIAN}

1. Karakteristik Responden

Tabel 1. Distribusi Frekuensi Karakteristik Responden Berdasarkan Jenis Kelamin

\begin{tabular}{cccc}
\hline No. & Jenis Kelamin & Frekuensi & Persentase (\%) \\
\hline 1. & Laki-laki & 9 & 25 \\
\hline 2. & Perempuan & 27 & 75 \\
\hline & Jumlah & 36 & 100 \\
\hline
\end{tabular}

Hasil penelitian berdasarkan karakteristik responden dapat dilihat pada tabel 1 di atas, menunjukkan bahwa dari 36 orang responden

2. Hasil Pemeriksaan $p H$ Saliva yang paling banyak adalah dengan jenis kelamin perempuan 27 orang (75\%).

Tabel 2. Distribusi Frekuensi $p H$ saliva Mahasiswa Tingkat I

Prodi D III Keperawatan Gigi Poltekkes Tasikmalaya.

\begin{tabular}{cccc}
\hline \multirow{2}{*}{ No } & pH saliva & Frekuensi & Persentase (\%) \\
\hline 1 & $p H 0-6,9$ (asam) & 21 & 58,3 \\
\hline 2 & $p H=7$ (netral) & 5 & 13,8 \\
\hline 3 & $p H 7,1-14$ (basa) & 10 & 27,9 \\
\hline & Jumlah & 36 & 100 \\
\hline
\end{tabular}

Hasil pemeriksaan $p H$ saliva pada responden dapat dilihat pada tabel 2 di atas, menunjukkan bahwa katagori asam menempati frekuensi yang paling tinggi, sebanyak 21 orang (58,3\%), dan yang paling sedikit adalah katagori $\mathrm{pH}$ netral, 5 orang $(13,8 \%)$

3. Hasil Pemeriksaan Decay

Tabel 3. Distribusi Frekuensi Nilai DMF-T Mahasiswa Tingkat I Prodi D III Keperawatan Gigi Poltekkes Tasikmalaya.

\begin{tabular}{clcc}
\hline No & Nilai DMF-T & Frekuensi & Persentase (\%) \\
\hline 1 & Sangat Rendah & 19 & 52,8 \\
\hline 2 & Rendah & 8 & 22,2 \\
\hline 3 & Sedang & 8 & 22,2 \\
\hline 4 & Tinggi & 1 & 2,8 \\
\hline 5 & Sangat Tinggi & 0 & 0 \\
\hline & Jumlah & 36 & 100 \\
\hline
\end{tabular}

Hasil pemeriksaan decay (nilai DMF-T) dapat dilihat pada Tabel 3, menunjukkan bahwa jumlah nilai DMF-T terbanyak ada pada nilai sangat rendah yaitu sebanyak 19 responden. Sedangkan katagori sangat tinggi tidak ada yang masuk satu responden pun. 
Tita K.D, Emma K.' Poltekkes Kemenkes Tasikmalaya; DMF-T, pH saliva, Mahasiswa.

4. Uji Statistik dengan Chi Square

Tabel 4. Analisis Hubungan $p H$ Saliva dengan nilai DMF-T pada Mahasiswa Tingkat I Prodi D III Keperawatan Gigi Poltekkes Tasikmalaya

\begin{tabular}{ccccc}
\hline \multirow{2}{*}{$\boldsymbol{p H}$ Saliva } & \multicolumn{3}{c}{ DMF-T } & \multirow{2}{*}{$\boldsymbol{P}$ - Value } \\
\cline { 2 - 4 } & $\begin{array}{c}\text { Sangat } \\
\text { Rendah }\end{array}$ & Rendah & Sedang & \\
\hline Asam & 13 & 3 & 5 & \multirow{2}{*}{0,540} \\
\hline Netral & 2 & 2 & 1 & \\
\hline Basa & 4 & 3 & 3 & \\
\hline Jumlah & 19 & 8 & 9 & \\
\hline
\end{tabular}

Tabel di atas menunjukkan bahwa nilai yang tertinggi adalah nilai $\mathrm{pH}$ saliva asam dengan kondisi DMF-T sangat rendah (13 responden). Berdasarkan hasil uji chi square didapatkan nilai $p$-value $=0,540$ yang berarti bahwa nilai $p$-value lebih dari 0,05 , sehingga

\section{PEMBAHASAN}

Berdasarkan hasil penelitian yang dilakukan di Jurusan Keperawatan Gigi Poltekkes kemenkes Tasikmalaya pada mahasiswa tingkat I diperoleh data bahwa jumlah mahasiswa yang termasuk kriteria $\mathrm{pH}$ saliva asam berjumlah 21 orang (58.3\%), netral 5 orang $(13.8 \%)$, sedangkan kriteria basa 10 orang $(27,9 \%)$. Hal ini berarti bahwa sebagian besar mahasiswa $p H$ salivanya bersifat asam. Menurut Astoeti (2006), proses karies gigi dapat disebabkan oleh kumpulan plak, makanan yang mengandung gula, saliva dan email. Proses karies dapat terjadi apabila saliva berada pada kondisi asam dengan $\mathrm{pH}$ \pm 5 , pH saliva yang asam dapat mempercepat proses demineralisasi, tetapi $\mathrm{pH}$ saliva bukan satu-satunya faktor penyebab karies. Karies disebabkan oleh interaksi multifaktor antara host (gigi dan saliva), mikroorganisme, substrat (karbohidrat), dan lamanya proses interaksi tersebut (Junaidi, 2004).

Penelitian Suwanto dan kawan-kawan didapatkan hubungan yang bermakna antara $\mathrm{pH}$ saliva dengan karies pada siswa SD (Suwanto, dkk, 2005). Hal ini dapat terjadi karena perbedaan komposisi gigi susu pada anak-anak dan gigi permanen pada orang dewasa. Gigi permanen mengandung lebih banyak bahan mineral daripada bahan
$\mathrm{H}_{0}$ tidak ditolak, kesimpulannya; tidak ada hubungan yang signifikan antara $\mathrm{pH}$ saliva dengan nilai DMF-T pada mahasiswa tingkat I Program D III Keperawatan Gigi Jurusan Keperawatan Gigi Poltekkes Kemenkes Tasikmalaya

organik, sebaliknya dengan gigi susu. Komposisi yang kaya mineral ini menyebabkan kristal enamel menjadi lebih padat. Kristal enamel yang padat sukar mengalami demineralisasi sehingga karies pada gigi anak-anak lebih cepat terjadi daripada pada orang dewasa (Behrman, et al, 1999).

Mikroorganisme yang dapat menyebabkan karies umumnya berasal dari jenis kokus gram positif. Bakteri ini dapat menempel pada gigi dan membentuk lapisan lunak dan lengket yang disebut plak. Plak dapat mengubah karbohidrat dari sisa makanan atau minuman menjadi asam sehingga terjadi proses demineralisasi gigi (Behrman, et al, 1999). Sisa makanan dan minuman yang mengandung karbohidrat akan menurunkan $\mathrm{pH}$ plak dengan cepat hingga level yang mampu menyebabkan demineralisasi gigi. pH saliva akan kembali ke pH normal membutuhkan waktu 30-60 menit, sehingga konsumsi karbohidrat yang berulang-ulang dapat menahan $\mathrm{pH}$ plak di bawah normal dan menyebabkan demineralisasi gigi. Peran mikroorganisme dan karbohidrat dalam pembentukan plak sesuai dengan teori asidogenik Miller yang menyatakan bahwa kerusakan gigi 
Tita K.D, Emma K.' Poltekkes Kemenkes Tasikmalaya; DMF-T, pH saliva, Mahasiswa.

merupakan proses kemoparasiter yang disebabkan oleh terbentuknya asam melalui proses fermentasi karbohidrat oleh bakteri sehingga terjadi dekalsifikasi email dan

\section{KESIMPULAN}

Mayoritas $p H$ saliva pada mahasiswa Tingkat I Program D III Jurusan Keperawatan Gigi Poltekkes Kemenkes Tasikmalaya ada pada katagori asam yang berjumlah 21 orang $(58,3 \%)$, sedangkan nilai DMF-T terbanyak

\section{KEPUSTAKAAN}

Agisty, (2010), Pengaruh Keju Terhadap Perubahan derajat Keasaman $(\mathrm{pH})$ Saliva pada Mahasiswa Tingkat I Jalur Umum Jurusan Kesehatan Gigi Politeknik Kesehatan Tasikmalaya Tahun 2010, KTI, Poltekkes Kemenkes Tasikmalaya

Behrman R.E., Kliegman R, dan Arvin A.M., (1999), Ilmu Kesehatan Anak Nelson Volume 1, diterjemahkan dari Nelson Textbook of Pediatrics oleh AS Wahab. 15.ed. Jakarta: EGC;.

Depkes R.I., (1995), Tata Cara Kerja Pelayanan Asuhan Kesehatan Gigi dan Mulut di Puskesmas, Bakhti Husada, Jakarta: Depkes RI.

Hanizar, N., (2005), Hubungan Air Ludah dengan Terjadinya Karies Gigi, KTI, Poltekkes, Tasikmalaya.

Houwink, dkk., (1993), Ilmu Kedokteran Gigi Pencegahan, UGM Press, Yogyakarta dentin. Asam akan melarutkan residu dari email dan dentin yang mengalami dekalsifikasi sehingga terbentuk lubang pada gigi (Behrman, et al, 1999).

ada pada katagori sangat rendah berjumlah 19 orang $(52,8 \%)$. Besaran nilai $p H$ saliva tidak ada hubungan secara signifikan dengan nilai DMF-T, nilai $p$-value 0,540 .

Junaidi, (2004), Hubungan Keparahan Karies Gigi Dengan Asupan Zat Gizi dan Status Gizi Anak Sekolah Dasar Kecamatan Lhoknga Kabupaten Aceh Besar. Yogyakarta: Universitas Gadjah Mada.Justiana, 2007, Specification $\mathrm{pH}$ Tester, Purewatercare.com

Kidd, E., Joyston, S., dan Bechal., (1992). Dasar-Dasar Karies Penyakit dan Penanggulangannya (terj), EGC, Jakarta.

Koonig, K.G., dan Hoogendoorn, H., (1982). Prevensi Dalam Kedokteran Gigi dan Dasar Ilmiahnya, Indonesian Dental Industries, Jakarta.

Kusmarjadi, D., (2010). Hypersalivasi-Ptylism, http://www.drdidispog.com

Miratania, (2010). pH Meter, http;//putrimyra. blogspot.com

Soebroto, I., (2009). Apa yang tidak di katakan dokter tentang kesehatan gigi anda, Bookmarks, Yogyakarta. 